University of Rhode Island

DigitalCommons@URI

The Rhode Island Current Conditions Index

Economics

$11-2013$

\title{
Rhode Island Current Conditions Index - November 2013
}

Leonard Lardaro

University of Rhode Island, lardaro@uri.edu

Follow this and additional works at: https://digitalcommons.uri.edu/ricci

Part of the Econometrics Commons

Terms of Use

All rights reserved under copyright.

\section{Recommended Citation}

Lardaro, Leonard, "Rhode Island Current Conditions Index -- November 2013" (2013). The Rhode Island Current Conditions Index. Paper 93.

https://digitalcommons.uri.edu/ricci/93

This Article is brought to you for free and open access by the Economics at DigitalCommons@URI. It has been accepted for inclusion in The Rhode Island Current Conditions Index by an authorized administrator of DigitalCommons@URI.For more information, please contact digitalcommons-group@uri.edu. 


\section{CURRENT CONDITIONS}

LEONARD LARDARO, URI

\section{Available Online: http:/ / www .Ilardaro.com/ current.htm Blog: http:/ / rieconomy.blogspot.com}

VOL XX

NUMBER 12

NOV 2013
The fourth quarter isn't playing out as well for Rhode Island as we might have hoped. For November, our state's positive but not exactly stunning momentum continued. As has been true for some time now, there was both good news and bad news concerning Rhode Island's economic performance. First, the good news (of sorts): although the Current Conditions Index for November fell to 67 from October's 75, several key indicators continue to display hopeful signs for the future months. While three of the CCl's five leading indicators improved this month, the two that failed to improve relative to last November both faced very difficult comps. The bad news once again emerges when we contrast November's performance for this year with that in 2012: for a fourth consecutive month, and the fifth time in six months, the $\mathrm{CCl}$ has failed to exceed its year-earlier value. Sadly, my earlier suspicion that a pattern of failure to improve on year-earlier values is proving to be correct. Let's hope this doesn't continue for much longer. Since the $\mathrm{CCl}$ 's readings in early 2013 were not terribly strong, we might find ourselves once again exceeding year-earlier values in just a few months. At any rate, what we are continuing to witness is a slowing in our rate of growth relative to the end of last year. This, by itself, is discouraging since our state's current rate of growth is not exactly going to cause whiplash. The ultimate test of how robust this recovery proves to be will be defined by our ability to accelerate from current rates of growth. While more rapid national growth will clearly help with this, Rhode Island's failure to meaningfully redefine itself for the information age (other than renaming the EDC) has left our state's obstacles to more rapid growth, most notably our non-competitive tax and cost structure, intact.

As stated earlier, for November, three of the CCl's five leading indicators improved. The other two were unable to escape the effects of very difficult "comps" from a year ago. US Consumer

\begin{tabular}{|c|c|}
\hline \multicolumn{2}{|c|}{ CCI Indicators - \% Change } \\
\hline Government Employment & -0.5 \\
\hline US Consumer Sentiment & -9.4 \\
\hline Single-Unit Permits & $30.1 Y$ \\
\hline Retail Sales & $1.4 \mathrm{Y}$ \\
\hline Employment Services Jobs & -1.3 \\
\hline Priv. Serv-Prod Employment & $1.4 \mathrm{Y}$ \\
\hline Total Manufacturing Hours & $5.6 \mathrm{Y}$ \\
\hline Manufacturing Wage & $1.7 \mathrm{Y}$ \\
\hline Labor Force & -2.1 \\
\hline Benefit Exhaustions & $-22.7 \mid Y$ \\
\hline New Claims & $-26.9 \mathrm{Y}$ \\
\hline Unemployment Rate (change) & $-1.0 \mid Y$ \\
\hline
\end{tabular}

Sentiment fell sharply $(-9.4 \%)$, in part because of a 29 percent rise one year ago. November marked the third consecutive decline for Sentiment. It remains in an uptrend at present that will likely continue as long as the stock market continues to rise. Employment Service Jobs, which includes temporary employment, a prerequisite to overall employment growth, fell for only the second time in over a year, declining by 1.3 percent. Should its uptrend reverse, this would pose problems as we move into 2014. One potentially hopeful thought: these recent declines might be revised away with the upcoming rebenchmarking of the 2013 data.

While our state's economic momentum continues to slow, pockets of substantial momentum remain, based on the performances of both the leading indicators contained in the $\mathrm{CCl}$ and several of its non-leading indicators. Even with these, it will be quite some time before we return to our prior peak in economic activity.

The remaining leading indicators improved in November. The recent surge in Single-Unit Permits, a leading indicator of housing, continued, as Permits rose by 30.1 percent compared to last November, as Rhode Island's housing sector continued to move well beyond its recession trough. New Claims for Unemployment Insurance, the most timely measure of layoffs, improved in November, falling by 26.9 percent. Unlike the leading indicators discussed earlier, even though this indicator is not in a well-defined downtrend, the most recent three months indicate that this might be changing. The final leading indicator, Total Manufacturing Hours, which measures strength in our manufacturing sector, rose by 5.6 percent in November, driven mainly by a large increase in the length of the workweek. This indicator has now improved for eleven of the last thirteen months.

Retail Sales have remained strong, in spite of a slowing in their rate of growth of late, Private Service-Producing Employment growth remained at or above one percent for the third consecutive month $(+1.4 \%)$, and our state's Labor Force declined yet again (for the eighth consecutive time). Along with this, our Unemployment Rate fell slightly over the month, although we were able to return to the \#1 slot nationally. Finally, Government Employment edged down a bit (-0.5\%).

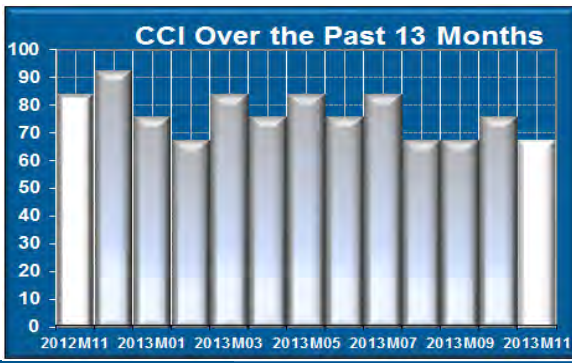

\section{DLT NOV Employment (SA, Y/Y)}

Gain

6,900

Loss

1,400

\section{THE BOTTOM LINE}

The fourth quarter this year hasn't proven to be as positive as was the case last year. At the present time, Rhode Island's economy finds itself at an inflection point, as our state's recovery has become somewhat less broadly based. The $\mathrm{CCl}$ has now failed to exceed its yearearlier value for four consecutive months which signals a slowing in our rate of growth as 2013 comes to an end. That's not a very happy way to end the year! In spite of this, a fair amount of momentum remains and Rhode Island will benefit from the accelerating pace of national activity. If Rhode Island ever reinvents itself, it will no longer be necessary for us to suffer through such self-inflicted mediocrity.

\begin{tabular}{|l|l|l|l|l|l|l|l|l|l|l|l|l|l|}
\hline & Jan & Feb & Mar & Apr & May & J un & J ul & Aug & Sep & Oct & Nov & Dec \\
\cline { 2 - 14 } & 2012 & $67 \uparrow$ & $58 \uparrow$ & 58 & $67 \uparrow$ & $67 \uparrow$ & $83 \uparrow$ & $58 \uparrow$ & $92 \uparrow$ & $75 \uparrow$ & $92 \uparrow$ & $83 \uparrow$ & $83 \downarrow$ \\
\cline { 2 - 12 } & 2013 & 75 & 67 & 83 & $75 \uparrow$ & 83 & 75 & $83 \uparrow$ & 67 & $67 \downarrow$ & 75 & 67 & \\
\hline
\end{tabular}

$\therefore \square \square \square$ 